\section{Buffer Components Tailor DNA Amplification with Arbitrary Primers}

\author{
G. Caetano-Anollés, \\ B.J. Bassam, ${ }^{1}$ and \\ P.M. Gresshoff
}

Plant Molecular Genetics, Institute of Agriculture and Center for Legume Research, The University of Tennessee, Knoxville, Tennessee 37901-1071

'Present address: Cooperative Research Centre for Tropical Plant Pathology, University of Queensland, Australia.
Molecular markers for genetic mapping, bulked segregant analysis, and general DNA fingerprinting of anonymous genomes can be generated easily by DNA polymerase-directed amplification with arbitrary oligonucleotide primers. ${ }^{(1-3)}$ Several multiple arbitrary amplicon profiling (MAAP) ${ }^{(4)}$ techniques have been used for this purpose, including random amplified polymorphic DNA (RAPD) analysis $^{(1)}$ and DNA amplification fingerprinting (DAF). ${ }^{(3)}$ MAAP markers can be used in breeding as amplificationbased DNA diagnostic tools with the potential of analyzing thousands of plant or animal individuals. Many amplification parameters influence the MAAP reaction. $^{(4,5)}$ In the PCR, the stringency of amplification can be adjusted by optimizing ionic components. ${ }^{(6)}$ This facilitates automation under a uniform temperature regimen. The influence of ionic components on MAAP has not been established, often resulting in the use of different parameters (like magnesium levels) in the amplification of templates with varying complexities. ${ }^{(4)}$ For example, consistent fingerprints can be obtained with relatively low levels of magnesium $(\sim 1.5 \mathrm{~mm})$ for templates of high complexity but higher levels $(\sim 6 \mathrm{~mm})$ are required in the amplification of lowcomplexity genomes. ${ }^{(5)}$ Similarly, some primers require different amplification stringencies for optimal performance. $\mathrm{Fi}$ nally, different eubacterial DNA polymerases result in variant fingerprints, ${ }^{(5,7,8)}$ an observation that can also be assigned to the recommended use of different enzyme buffers. Her $r$, we explore the influence of different buffer components on the DAF reaction and their ability to tailor fingerprint pattern.

\section{MATERIALS AND METHODS}

We studied the interaction of amplification buffer components and magnesium (as $\mathrm{MgCl}_{2}$ and $\mathrm{MgSO}_{4}$ ) using two primer-template combinations, soybean (Glycine max L.) cv. Bragg DNA with primer CCGAGCTG and nematode Heterodera glycines DNA with primer GTAACGCC. Nematode race 3 juveniles were isolated from soybean $\mathrm{cv}$. Hutcheson. DAF reactions $(20 \mu \mathrm{l})$ containing $3 \mu \mathrm{M}$ primer, $200 \mu \mathrm{M}$ of each deoxynucleoside triphosphate, and $\sim 0.1$ and $1 \mathrm{ng} / \mu \mathrm{l}$ of soybean or nematode DNA, respectively, were initially op ${ }^{\star} \mathbf{i}$ mized with $0.3 \mathrm{U} / \mu \mathrm{l}$ of Stoffel enzyme
(Perkin-Elmer Cetus, Norwalk, CT), a truncated derivative of Thermus aquaticus DNA polymerase, as described previously ${ }^{(5)}$ and amplified in 35 cycles of 30 $\mathrm{sec}$ at $96^{\circ} \mathrm{C}, 30 \mathrm{sec}$ at $30^{\circ} \mathrm{C}$, and $30 \mathrm{sec}$ at $72^{\circ} \mathrm{C}$ in a recirculating hot-air thermocycler (Bios, New Haven, CT). Amplification products were separated using polyester-backed $5 \%$ polyacrylamide/urea minigels ${ }^{(9)}$ and stained with silver. ${ }^{(10)}$ Wells were loaded with $3 \mu$ l of a 1:10 dilution of each amplification reaction mixed with $3 \mu$ l of loading buffer ( $5 \mathrm{M}$ urea and $0.02 \%$ xylene cyanol FF) and run at $100 \mathrm{~V}$ for $\sim 80 \mathrm{~min}$.

\section{RESULTS AND DISCUSSION}

Reproducible DNA patterns were obtained with each of several formulations representative of buffers from commercially available DNA polymerases. Experimental consistency was tested by electrophoretic separation of undiluted DNA amplification products so as to reveal even the faint "tertiary" products (as defined previously.) ${ }^{(5)}$ Routinely, diluted reaction products are loaded in the gels. Reproducible DAF profiles were generated from DNA obtained from replicate soybean plants in independent experiments done over a period of 6 months. Similarly, repeated amplification of a DNA sample rendered indistinguishable fingerprints. Quantitative variation in DAF patterns of soybean has been estimated by scanning densitometry. ${ }^{(11)}$ In these studies mobility and band intensity was highly reproducible when independently isolated or amplified DNA samples were analyzed. Some variability in band intensity was observed when a single sample was silver-stained repeatedly.

Figure 1 shows profiles obtained from nematode DNA amplified in the presence of either $\mathrm{MgCl}_{2}$ or $\mathrm{MgSO}_{4}$. Although the magnesium counterion used had in some cases a profound effect on fingerprint pattern, the use of $\mathrm{MgSO}_{4}$ appeared advantageous. Other cations, such as $\mathrm{Ca}^{2+}, \mathrm{Ba}^{2+}$, and $\mathrm{Sr}^{2+}$, interfered with and failed to substitute for magnesium-mediated amplification (not shown). Some formulations produced products in the high- and low-molecular-weight range (cf. lane 5), others produced only products of low-molecular weight (cf. lane 7), and some inhibited amplification. The use of bovine serum albumin (BSA) appeared to increase yield 


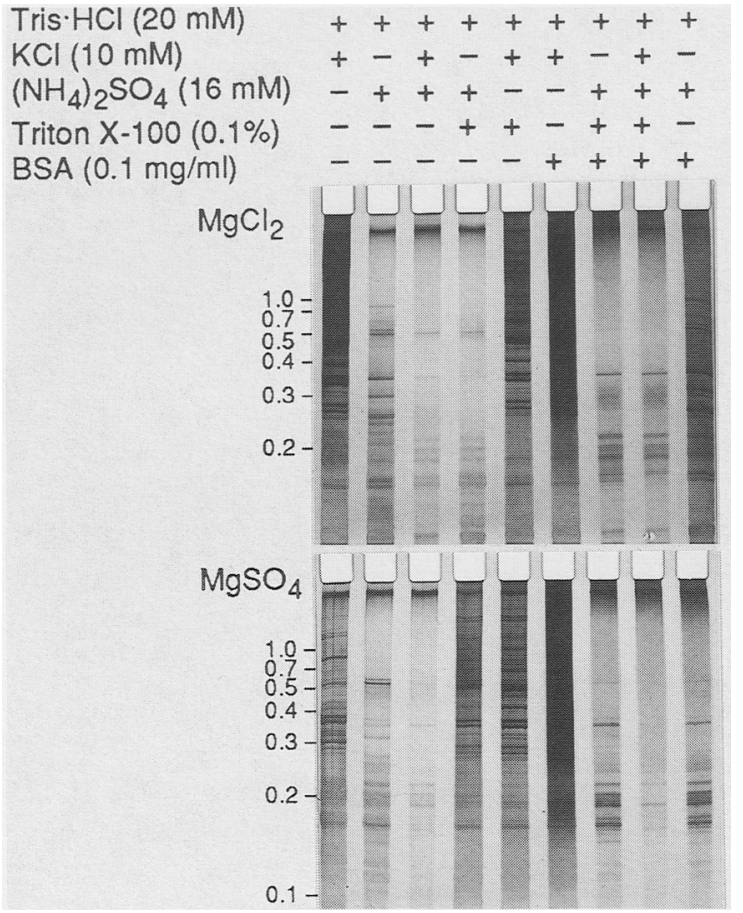

FIGURE 1 Influence of ionic components on DAF profiles. Nematode DNA was amplified using different buffers (adjusted to $\mathrm{pH} \mathrm{8.4)}$ ) and $4 \mathrm{~mm}$ magnesium concentrations. Molecular mass markers are given in kilobase pairs.

but interfered with silver staining. The use of gelatin reduced yield and reproducibility (not shown).

The inferred positive effects of Triton $\mathrm{X}-100, \mathrm{KCl}$, and $\left(\mathrm{NH}_{4}\right)_{2} \mathrm{SO}_{4}$ (observed in Fig. 1) were studied further (Fig. 2). Triton $\mathrm{X}-100$ in some buffer formulations increased amplification yield (especially when using $\mathrm{MgSO}_{4}$ ). However, increasing Triton X-100 concentrations decreased the yields of products in the high-molecular-weight range generated from $\mathrm{MgCl}_{2}$-mediated amplifications (Fig. 2). Concentrations levels higher than $0.5 \%$ were inhibitory. Reproducible patterns were obtained with $<20 \mathrm{mM} \mathrm{KCl}$ and $<16 \mathrm{mM}\left(\mathrm{NH}_{4}\right)_{2} \mathrm{SO}_{4}$ concentrations for nematode DNA, or $<30 \mathrm{~mm} \mathrm{KCl}$ and $<24 \mathrm{mM}\left(\mathrm{NH}_{4}\right)_{2} \mathrm{SO}_{4}$ for soybean DNA; higher concentrations were inhibitory. As observed in the $\mathrm{PCR}^{(6)}$ and within observed limits, $\left(\mathrm{NH}_{4}\right)_{2} \mathrm{SO}_{4}$ increased amplification stringency while $\mathrm{KCl}$ lowered it. The use of $\mathrm{MgSO}_{4}$ allowed amplifica-

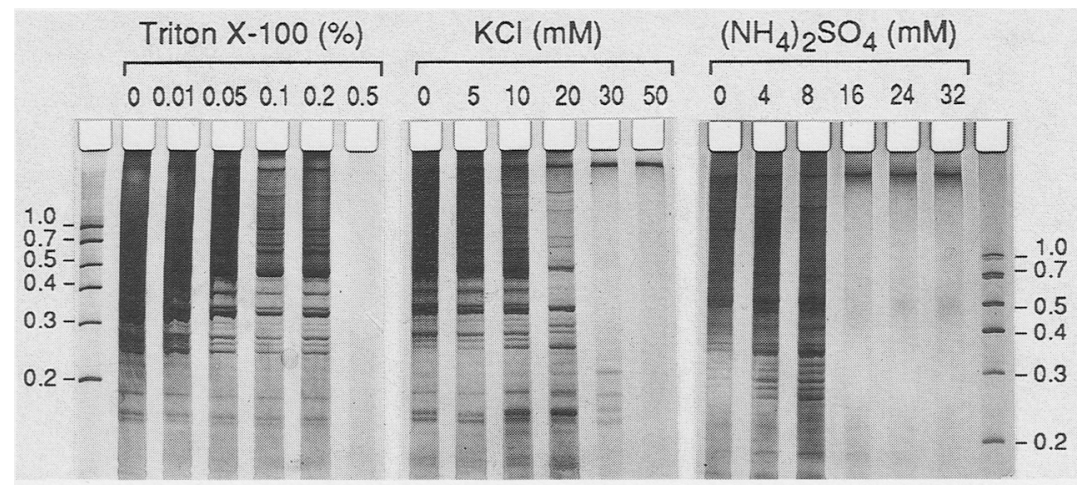

FIGURE 2 Effect of Triton $\mathrm{X}-100, \mathrm{KCl}$, and $\left(\mathrm{NH}_{4}\right)_{2} \mathrm{SO}_{4}$ concentrations on DAF of nematode DNA. Default concentrations were $0.1 \%$ Triton X-100, $20 \mathrm{~mm}$ Tris- $\mathrm{HCl}, 10 \mathrm{mM} \mathrm{KCl}$ (ammonium optimization shown uses buffers without $\mathrm{KCl}$ ), and no $\left(\mathrm{NH}_{4}\right)_{2} \mathrm{SO}_{4}$. Experiments shown were done using $4 \mathrm{mM} \mathrm{MgCl}_{2}$, and buffers were adjusted to $\mathrm{pH}$ 8.4. Molecular mass markers are given in kilobase pairs. tion in the presence of $\sim 50 \%$ higher ammonium levels. The presence of $\mathrm{KCl}$ had the opposite effect, decreasing the concentrations allowed by half (Fig. 1; data not shown).

Optimization resulted in three candidate buffer formulations that used $\mathrm{MgSO}_{4}$ and increased yield and molecular weight range of products amplified: TTNK10 (20 mM Tris- $\mathrm{HCl}, 0.1 \%$ Triton $\mathrm{X}-100,4 \mathrm{~mm}\left(\mathrm{NH}_{4}\right)_{2} \mathrm{SO}_{4}$, and $10 \mathrm{~mm}$ $\mathrm{KCl}$ ), TTK10 and TTK30 (20 mM Tris- $\mathrm{HCl}$, $0.1 \%$ Triton $\mathrm{X}-100$, and $10 \mathrm{~mm}$ or $30 \mathrm{~mm}$ $\mathrm{KCl}$, respectively). In a set of experiments, soybean and nematode DNA were amplified in the presence of $4 \mathrm{~mm}$ $\mathrm{MgSO}_{4}$ using these buffer formulations. Figure $3 \mathrm{~A}$ shows the effect of $\mathrm{pH}$ on the amplification of nematode DNA when using two of these buffers. While higher $\mathrm{pH}$ decreased amplification efficiency of TTK10, buffer TTNK10 was tolerant of $\mathrm{pH}$ variation. Buffer TTK30 behaved much like TTK10. Similar results were obtained with soybean DNA. These buffers tolerated wide changes in magnesium concentration, and their activity was independent of template complexity. As an example, Figure 3B shows consistent amplification of soybean DNA using TTK30 over a wide range of magnesium concentrations. DNA profiles exhibiting high yield of low-molecular-weight products were also obtained using 10-20 mM tricine as amplification buffer (not shown). Despite optimization, our formulations did not produce adequate DAF profiles with other DNA polymerases. In fact, optimized buffers had a deleterious effect on the activity of some enzymes (like Vent $_{R}$ DNA polymerase, New England Biolabs, Beverly, MA), probably because optimized conditions depart even farther from those required for their optimal activity and specificity. This argues against a "consensus" buffer for enzymes of different sources.

Our results show that buffer components can be important determinants of DAF pattern, favoring in some instances the amplification of high- or low-molecular-weight products. DNA fingerprinting studies should make use of these tailoring possibilities. DAF profiles from organisms ranging from $\lambda$ phage to mammals can be reproducibly generated with our selected buffer formulations using a uniform $4 \mathrm{~mm} \mathrm{MgSO}_{4}$ concentration and uniform temperature regimen. In particular, buffer TTNK10 has been 


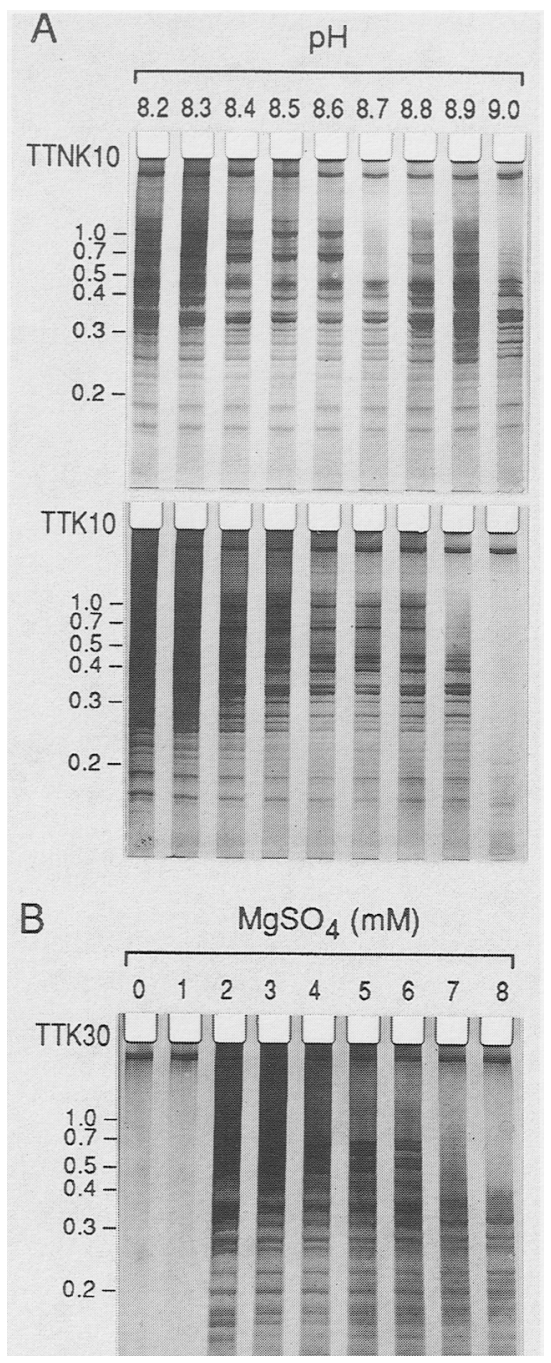

FIGURE 3 Influence of $\mathrm{pH}$ and $\mathrm{MgSO}_{4}$ concentration on DAF profiles. $(A)$ Effect of $\mathrm{pH}$ on the amplification of nematode DNA in the presence of $4 \mathrm{mM} \mathrm{MgSO}_{4}$, using TTNK10 and TTK10 buffer formulations adjusted to the indicated $\mathrm{pH}$. (B) Effect of $\mathrm{MgSO}_{4}$ concentration on the amplification of soybean DNA using TTK30 adjusted to $\mathrm{pH}$ 8.6. Molecular mass markers are given in kilobase pairs.

widely used for reproducible amplification of these templates with minihairpin oligonucleotide primers. ${ }^{(12)}$ Optimized buffers will facilitate automation analysis of DNA for genome identification, construction of DNA marker data bases, and diagnostic applications.

\section{ACKNOWLEDGMENTS}

This work was supported by an endowment to the Racheff Chair in Plant Molecular Genetics.

\section{REFERENCES}

1. Williams, J.G.K., A.R. Kubelik, K.J. Livak, J.A. Rafalski, and S.V. Tingey. 1990. DNA polymorphisms amplified by arbitrary primers are useful as genetic markers. $\mathrm{Nu}$ cleic Acids Res. 18: 6531-6535.

2. Welsh, J. and M. McClelland. 1990. Fingerprinting genomes using PCR with arbitrary primers. Nucleic Acids Res. 18: 7213-7218.

3. Caetano-Anollés, G., B.J. Bassam, and P.M. Gresshoff. 1991. DNA amplification fingerprinting using very short arbitrary oligonucleotide primers. BioTechnology 9: 553-557.

4. Caetano-Anollés, G. 1993. Amplifying DNA with arbitrary oligonucleotide primers. PCR Methods Applic. 3: 85-94.

5. Bassam, B.J., G. Caetano-Anollés, and P.M. Gresshoff. 1992. DNA amplification fingerprinting of bacteria. Appl. Microbiol. Biotechnol. 38: 70-76.

6. Blanchard, M.M., P. Taillon-Miller, P. Nowotny, and V. Nowotny. 1993. PCR buffer optimization with uniform temperature regimen to facilitate automation. $P C R$ Methods Applic. 2: 234-240.

7. Schierwater, B. and A. Ender. 1993. Different thermostable DNA polymerases may amplify different RAPD products. Nucleic Acids Res. 21: 4647-4648.

8. Aldrich, J. and C.A. Cullis. 1993. RAPD analysis in flax: Optimization of yield and reproducibility using KlenTaq 1 DNA polymerase, Chelex 100, and gel purification of genomic DNA. Plant Mol. Biol. Rep. 11: 128-141.

9. Caetano-Anollés, G. and B.J. Bassam. 1993. DNA amplification fingerprinting using arbitrary oligonucleotide primers. Appl. Biochem. Biotechnol. 42: 189-200.

10. Bassam, B.J., G. Caetano-Anollés, and P.M. Gresshoff. 1991. Fast and sensitive silver staining of DNA in polyacrylamide gels. Anal. Biochem. 196: 80-83.

11. Gresshoff, P.M. and A.K. MacKenzie. 1994. Low experimental variability of DNA profiles generated by arbitrary primer based amplification (DAF) of soybean. Chin. J. Bot. 6: 1-6.

12. Caetano-Anollés, G. and P.M. Gresshoff. 1994. DNA amplification fingerprinting using arbitrary mini-hairpin oligonucleotide primers. BioTechnology 12: 619-623.

Received April 18, 1994; accepted in revised form June 15, 1994. 


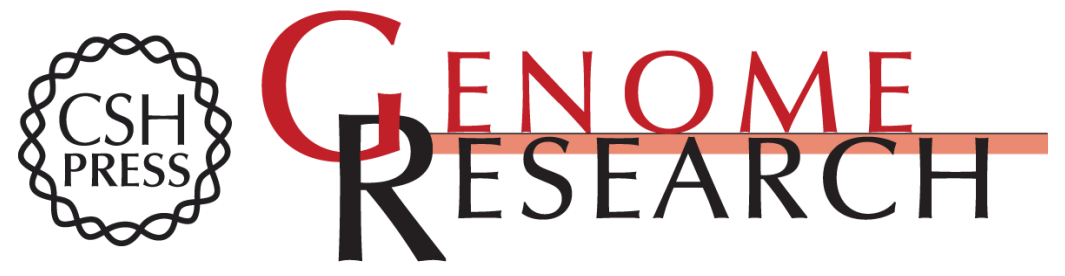

\section{Buffer components tailor DNA amplification with arbitrary primers.}

G Caetano-Anollés, B J Bassam and P M Gresshoff

Genome Res. 1994 4: 59-61

\section{License}

Email Alerting Service

Receive free email alerts when new articles cite this article - sign up in the box at the top right corner of the article or click here.

\section{Affordable, Accurate} Sequencing.

To subscribe to Genome Research go to: https://genome.cshlp.org/subscriptions 